\title{
Recommendations for Risk Categorization and Prophylaxis of Invasive Fungal Diseases in Hematological Malignancies: A Critical Review of Evidence and Expert Opinion (TEO-4)
}

\author{
Hematolojik Malignitelerdeki Invazif Fungal Enfeksiyon \\ Riskinin Belirlenmesi ve Profilaksi: Kanttlara Eleştirel Bakış ve \\ Türk Uzman Görüşleri (TUG-4)
}

Can Boğa 1 , Zahit Bolaman², Seçkin Çağırgan ${ }^{3}$, İhsan Karadoğan ${ }^{4}$, Mehmet Ali Özcan ${ }^{5}$, Fahir Özkalemkaş6, Rabin Saba ${ }^{7}$, Mehmet Sönmez 8 , Esin Şenol ${ }^{9}$, Hamdi Akan10, Murat Akovall

${ }^{1}$ Basskent University Faculty of Medicine Hospital, Department of Hematology, Adana, Turkey

2Adnan Menderes University Faculty of Medicine, Division of Hematology, Aydın, Turkey

${ }^{3}$ Medical Park İzmir Hospital, Clinic of Hematology and Bone Marrow Transplantation Center, İzmir, Turkey

${ }^{4}$ Medstar Antalya Hospital, Clinic of Hematology and Stem Cell Transplantation, Antalya, Turkey

${ }^{5}$ Dokuz Eylül University Faculty of Medicine, Department of Hematology, İzmir, Turkey

${ }^{6}$ Uludağ University Faculty of Medicine, Department of Hematology, Bursa, Turkey

${ }^{7}$ Medstar Antalya Hospital, Clinic of Infectious Diseases, Antalya, Turkey

${ }^{8}$ Karadeniz Technical University Faculty of Medicine, Department of Hematology, Trabzon, Turkey

${ }^{9}$ Gazi University Faculty of Medicine, Department of Infectious Diseases, Ankara, Turkey

10Ankara University Faculty of Medicine, Department of Hematology, Ankara, Turkey

${ }^{11}$ Hacettepe University Faculty of Medicine, Department of Infectious Diseases, Ankara, Turkey

\begin{abstract}
:
This is the last of a series of articles on invasive fungal infections prepared by opinion leaders in Turkey. The aim of these articles is to guide clinicians in managing invasive fungal diseases in hematological malignancies and stem cell transplantation based on the available best evidence in this field. The previous articles summarized the diagnosis and treatment of invasive fungal disease and this article aims to explain the risk categorization and guide the antifungal prophylaxis in invasive fungal disease.
\end{abstract}

Key Words: Hematological malignancy, Invasive fungal infections, Prophylaxis, Risk

Özet:

Bu makale Türkiye'de invazif fungal enfeksiyon ile uğraşan uzmanlar tarafından hazırlanan bir seri yazının sonuncusudur. Bu makaleler hematolojik malignitelerde ve kök hücre nakli hastalarında invazif fungal hastalıkların yönetimini eldeki kanıtların ışı̆̆ında en iyi hale getirmeyi amaçlamaktadır. İlk yazılar tanı ve tedaviyi özetlerken, bu makale invazif fungal hastalıkta risk kategorizasyonu ve profilaksiyi ele almaktadır.

Anahtar Sözcükler: Hematolojik malignite, İnvazif fungal enfeksiyon, Profilaksi, Risk

Address for Correspondence: Hamdi AKAN, M.D.,

Ankara University Faculty of Medicine, Department of Hematology, Ankara, Turkey

Phone: +90 5324242640 E-mail: hamdiakan@gmail.com

Received/Geliş tarihi : July 05, 2014

Accepted/Kabul tarihi : October 17, 2014 


\section{Introduction}

\section{Dr. Murat Akova}

Invasive fungal diseases (IFDs) continue to be an important cause of morbidity and mortality during the course of disease in patients with hematological malignancies and/or stem cell transplantation [1]. The lack of a cheap, easily applied diagnostic test with high sensitivity and specificity, as well as the serious mortality caused by the delay in diagnosis, has brought prevention of fungal infections to the forefront. While recently developed effective new antifungal medications with a wide spectrum of activity make prophylactic application attractive in high-risk patient groups, the wide use of serological and molecular biological diagnostic tools, like high-resolution computerized tomography examinations, serum galactomannan and beta-D-glucan tests, and PCR applications provides effective treatment options for selected patients in the early period [2]. The most important concerns about prophylaxis are additional costs, unwanted side effects due to antifungal use, and development of resistance due to the use of unnecessary antifungal antibiotics in many patients in order to prevent fungal infection-related mortality in one patient. Therefore, before routine antifungal prophylaxis (AFP) is given to high-risk patient groups, the abovementioned risk-benefit relationship should be necessarily reviewed. If an example is to be given, in order to decrease infection incidence by $50 \%$, the number of patients who should receive prophylaxis is 100 in an environment where fungal infection prevalence is $2 \%$, and this figure drops to 44 in the event that the prevalence is $4.5 \%$ [3]. Another point that should be kept in mind before application of prophylaxis is that although a decrease in fungal infection incidence and fungal-related mortality has been provided by AFP in numerous clinical studies performed to date, only 2 studies have been able to show a decrease in the general mortality of high-risk patients [4]. All these findings prove that selective action should be taken in high-risk patients regarding AFP.

\section{Determination of Risk and Targets of Prophylaxis}

\section{Dr. Fahir Özkalemkaş}

Patients with hematological malignancies and allogeneic stem cell transplantation are the primary risk groups for IFD $[5,6]$. It has been known for a long time that early treatment initiation in patients with IFD is one of the major determinants of successful treatment and decreased mortality $[7,8,9]$. Despite all the recent advances in diagnostic testing, the absence of rapid and reliable diagnostic tests in IFD diagnosis enhances the importance of risk determination. When the prevalence and mortality rates are taken into consideration, well-defined high-risk patients constitute the group that will benefit from the prophylactic use of an effective antifungal agent. Therefore, determination of the correct risk level forms the basis of AFP. Furthermore, besides an increase in mortality, IFDs lead to delays in scheduled treatments (chemotherapy, stem cell transplantation), longer hospital stays, and increased treatment costs $[10,11,12,13]$.

Invasive aspergillosis and invasive candidiasis are the most important entities of IFD. A third important group is invasive mucormycosis infection, with a relatively low prevalence but a high mortality rate [5,6]. Apart from common risk factors such as neutropenia and long-term myelosuppression, risk profile varies depending on the causative agent. For example, while the presence of numerous spores in inspired air and factors facilitating the passage of these spores through respiratory mucous membranes and reduced phagocytosis in the tissues play the major role in aspergillosis infections, diminished general phagocytic activity, dense colonization in the gastrointestinal tract mucosa, and mucosal damage due to chemo-/radiotherapy come to the forefront in invasive candidiasis. For mucormycosis, in addition to defective phagocytosis, other factors such as prior steroid use and the presence of metabolic acidosis should also be taken into consideration $[1,5,14,15]$.

Hematological malignancies are widely heterogeneous in terms of risk. Among patients with hematological malignancies, acute leukemia patients, particularly those with acute myeloid leukemia (AML) receiving remission induction chemotherapy, are at significantly higher risk [6,13]. Highrisk myelodysplastic syndrome (MDS) is treated similarly to AML, as both have similar biological behavior; hence, MDS patients receiving remission induction chemotherapy are accepted to have the same risk profile as AML patients [16]. Likewise, hematopoietic stem cell transplantation patients are also heterogeneous. Risk is especially lower in patients with autologous transplantation than in those with allogeneic transplantation. Among allogeneic stem cell recipients, risk is significantly increased in those with graft-versus-host disease (GVHD) and long-term steroid use [17]. Another point that should not be forgotten is that risk profile may change over time due to the use of new treatment agents. For instance, the use of new monoclonal antibodies may alter the risk profile of chronic lymphocytic leukemia patients who are considered to be at low risk [18]. Similarly, use of new protocols in both the preparative regimen and GVHD prophylaxis in allogeneic stem cell transplantation, different stem cell sources (bone marrow, peripheral blood, umbilical cord blood), donor type (unrelated donors, relatives with perfect or partial match), stem cell manipulation (T-cell reduction), and superimposed infections (cytomegalovirus, respiratory syncytial virus infections) may lead to remarkable changes in the risk profile $[10,17,19,20,21,22,23,24,25]$. 
Apart from the comorbid conditions, the most important parameter in IFD development is neutropenia [26]. Both the depth and duration of neutropenia are important; more recently, an index taking these 2 parameters into account was reported to be important in predicting invasive mold infections [27]. In allogeneic transplants, in addition to neutropenia, development of long-term lymphopenia particularly enhances the risk of invasive aspergillosis [17].

Although specific polymorphisms (toll-like receptor 4, plasminogen alleles, dectin-1, TNF-1A) in some genes affecting natural immunity have been reported in recent years to make significant changes in invasive aspergillosis risk, these parameters are far from practical for use in the determination of treatment approach [28,29,30,31,32,33]. A recent study demonstrated that genetic deficiency of pentraxin 3 (PTX3) affects the antifungal capacity of neutrophils and may contribute to the risk of invasive aspergillosis in patients treated with hematopoietic stem cell transplantation [34].

Finally, in daily practice, particularly in Turkey, it is wise to underline the importance of environmental factors such as 'air quality' and personal factors like 'colonization' and 'prevention' in risk determination. Causative molds in the air may be at different concentrations in different geographic regions and may show seasonal variations in the same region $[1,20,35]$. In this respect, positive-pressure HEPA filters can be of critical importance in reducing the risk in risky regions and periods. Colonization during hospitalization is considered among the risk factors [36]. Other environmental control measures, hand-washing being the leading one, may reduce the risk [37].

\section{Timing of Prophylaxis}

\section{Dr. Esin Şenol}

There is no standard approach or recommendation regarding the optimal timing of prophylaxis in the guidelines and prophylaxis protocols. It is understood from prophylaxis studies that prophylaxis initiation times are different: at the time of hospitalization, or at the beginning or at the end of chemotherapy. In 2 important studies on primary prophylaxis using posaconazole, AML or MDS patients receiving chemotherapy had prophylaxis initiated together with chemotherapy in those not using anthracycline or $24 \mathrm{~h}$ after anthracycline in those using anthracycline. It was planned to be continued until resolution of neutropenia (ANC>500/ $\mathrm{mm}^{3}$ ), fungal infection development, or for 12 weeks [mean of 23 days (1-110 days, 29 \pm 21 )]. In patients with allogeneic stem cell transplantation and GVHD, it was planned to be given at the time of development of acute GVHD of 2-4 degree or chronic disseminated GVHD at a dose of $1 \mathrm{mg} / \mathrm{kg}$ /day for acute GVHD and $0.8 \mathrm{mg} / \mathrm{kg}$ every other day for chronic GVHD, or at the beginning of 2 or more immunosuppressive agents without steroids, and scheduled to be continued for 112 days $[38,39]$. The reason for starting prophylaxis along with chemotherapy is that the oral antifungals used for prophylaxis reach their plasma saturation levels in the neutropenic period when fungal infection risk is the highest. This period is 5 days if voriconazole is used orally and 7-10 days if posaconazole is used $[2,40,41]$. However, there is concern that the azole antifungals mostly used for prophylaxis may interact with drugs used in chemotherapy regimens.

Fluconazole prophylaxis (not involving molds) is given to allogeneic stem cell transplantation recipients before engraftment, in the beginning or immediately after the preparative regimen. There is a strong recommendation for giving prophylaxis for at least 3-6 months after engraftment; however, this period can be prolonged if treatment-related immunosuppression is caused by drugs such as corticosteroids [42].

The single remarkable end-point for the timing of prophylaxis termination for autologous stem cell transplantation recipients and for patients receiving AML/MDS chemotherapy is the resolution of neutropenia. Additionally, prophylaxis is discontinued in the event of conditions like drug intolerance, development of a new fungal infection, and drug-related side effects. However, there are still uncertainties in the timing of termination as well as the timing of initiation of prophylaxis, especially in allogeneic stem cell transplantation recipients [43].

\section{Agents Used in Prophylaxis}

Dr. Mehmet Sönmez

Polyene, azole, and echinocandin-class antifungal agents, including fluconazole, itraconazole, posaconazole, voriconazole, micafungin, anidulafungin, caspofungin, amphotericin B deoxycholate, and liposomal amphotericin B, have been used for AFP [38,39,44,45,46,47,48,49,50,51,52]. Toxicity, drug interactions, costs, effects of the used antifungal agent on fungal diagnostic tests, and risk of developing resistant fungal infections should be taken into account in patients receiving antifungal prophylaxis. While a metaanalysis of the studies comparing the efficacy of antifungal prophylaxis in patients receiving AML/MDS induction treatment or in those undergoing allogeneic hematopoietic stem cell transplantation showed that antifungal prophylaxis decreased IFD prevalence and IFD-related mortality, similar effects were not observed in patients undergoing autologous stem cell transplantation. The incidence of IFD, and especially the incidence of Aspergillus infections, was found to be lower in patients receiving prophylaxis for molds. However, side effectrelated discontinuation of the drug was found to be higher compared to the fluconazole-treated group. It was noted that that overall mortality was not changed $[11,51,53]$. Currently, 
echinocandins, apart from micafungin and anidulafungin, and polyene-group antifungals are not considered to be preferable prophylactic agents in spite of their wide antifungal activity spectrum because of intravenous use, side effect profiles, costs, and absence of sufficient data on prophylactic use. Therefore, azole-group drugs are generally preferred in antifungal prophylaxis. Although itraconazole, included in this group of drugs, is an effective agent, high discontinuation rates due to gastric intolerance, drug interactions, and variable bioavailability restrict its use. Fluconazole, with the lowest rate of side effects and drug interactions and an activity spectrum limited to Candida species, is recommended in patients undergoing allogeneic hematopoietic stem cell transplantation during neutropenia, but necessitates mold testing during prophylaxis. The demonstration that posaconazole is more effective in preventing IFD development in comparison to fluconazole led to the preferential use of posaconazole prophylaxis in AML/MDS patients receiving induction treatment and in those who developed GVHD after allogeneic hematopoietic stem cell transplantation. However, the necessity of taking posaconazole on a full stomach along with food rich in fats, drug interactions, and the necessity of drug level monitoring are among the factors that restrict its usage. Likewise, while voriconazole, an azole-group drug that should be used in therapeutic levels, is recommended to be used in patients undergoing allogeneic stem cell transplantation, it requires careful monitoring of hepatotoxicity, neurotoxicity, and drug interactions $[2,54,55,56,57,58,59,60]$. Furthermore, voriconazole is recommended to be used for secondary prophylaxis in patients with prior Aspergillus infection who require retreatment or allogeneic hematopoietic stem cell transplantation. On the other hand, in hospitals with a mold incidence of $<5 \%$ and with HEPA filtration, monitoring of patients with diagnostic tests without antifungal prophylaxis for molds may also be a suitable approach $[60,61,62]$.

\section{Monitoring of Prophylaxis}

Dr. Rabin Saba

After a decision is made about AFP and the drug that will be used, the efficacy and side effects of the chosen drug should be monitored. Primarily, the interaction of the drug with food and other drugs should be evaluated. The bioavailability of voriconazole increases when taken on an empty stomach, itraconazole capsule with food, and posaconazole with fatty food. The bioavailability of proton pump inhibitors or $\mathrm{H} 2$ receptor blockers decreases when used together with posaconazole or itraconazole $[2,63]$. Considering drug interactions, special care should be taken when using triazoles, which can be both the substrate and the inhibitor of cytochrome P (CYP) 450 isoenzymes. Each drug should be considered individually. For instance, posaconazole is metabolized by glucuronidation, not by the CYP system; however, it is a weak inhibitor of CYP 3A4. For this reason, if taken together with drugs inducing CYP enzymes, the serum concentration of triazoles other than posaconazole decreases. If taken together with triazoles, the serum concentration of drugs metabolized by CYP enzymes increases. It is contraindicated to use sirolimus with voriconazole and posaconazole [64]. When interactions with chemotherapeutic agents are considered, the best known example is the interaction between itraconazole and vincristine [65]. The increased neurotoxicity (by crossing the blood brain barrier) and the organ toxicity of vincristine is noteworthy. Antifungal drugs should also be monitored in terms of side effects [66]. While triazoles are particularly monitored regarding tolerability and hepatotoxicity, amphotericin B should be monitored in terms of infusion-related side effects, nephrotoxicity, and hypokalemia. The point that should not be forgotten is that prophylaxis should be used in conditions where the protective effects of prophylaxis are superior to the expected side effects. Discontinuation of the drug and/or switching to another drug should be considered in the case of side effects.

\section{Drug Level Monitoring}

While therapeutic drug monitoring generally gains importance for mold-active triazoles (itraconazole, voriconazole, and posaconazole), it is not recommended for echinocandin and polyene-group antifungals [2,63]. Measurement of serum concentrations is especially recommended in pharmacokinetically unstable patients (children, neonates, critical patients, those with organ dysfunction, etc.), in the suspicion of incompatibility, in the presence of drug interactions, when switching from the intravenous form of the drug to the oral form, and in patients with absorption problems such as diarrhea or GVHD.

\section{Itraconazole}

The bioavailability of itraconazole is variable and shows changes depending on the formulation. Bioavailability of the oral capsules increases with food and gastric acidity. The oral solution, which has better bioavailability, is much better absorbed when taken on an empty stomach and is not affected by gastric acidity. As the rates of breakthrough infections and mortality were found to be significantly higher at lower drug levels, it is required to maintain the serum concentrations at $>8 \mathrm{mg} / \mathrm{L}$ (measuring both itraconazole and hydroxyitraconazole levels) as measured by bioassay method, at $<0.5-1 \mathrm{mg} / \mathrm{L}$ by high-performance liquid chromatography and mass spectrometry, and at $<17 \mathrm{mg} / \mathrm{L}$ by bioassay to minimize gastrointestinal, neurological, and hepatic toxicity $[67,68]$. As the drug concentration will achieve a steady state within 2 weeks, the measurements should begin after 7 days $[2,63,64,65,66,67,68]$. 


\section{Voriconazole}

As voriconazole shows nonlinear pharmacokinetics, changes in the dosage are not similarly reflected. Although the efficacy of prophylaxis monitoring has not been clearly demonstrated, serum concentrations are to be maintained at $1-5 \mathrm{mg} / \mathrm{L}$ with regard to toxicity $[63,69,70]$. It is recommended that serum concentrations should be measured within and after 5 days of use.

\section{Posaconazole}

Due to its long half-life $(34 \mathrm{~h})$, and because the drug concentration achieves a steady state within 7 days, the first measurement is recommended to be performed after 1 week of use [63]. The plateau concentration is recommended to be $>0.7 \mathrm{mg} / \mathrm{L}$ for efficient prophylaxis $[63,71,72]$. It was shown that the alveolar intracellular posaconazole level was 40-50 times greater than outside the cell and this might explain the efficacy of posaconazole prophylaxis in patients with low serum posaconazole levels [73]. As the alveolar tissue concentration is important for posaconazole, it has been stated that alveolar concentration rather than serum concentration will be required to be measured in the future [63].

In the follow-up of patients receiving mold prophylaxis for fungal infections, special care should be given to diagnostic test interpretation. Notably, the sensitivity of the galactomannan test is decreased in patients receiving posaconazole and voriconazole prophylaxis [74]. A study evaluating the place of Aspergillus polymerase chain reaction and galactomannan antigen in bronchoalveolar lavage fluid in diagnosis showed that anti-mold prophylaxis decreases sensitivity [75]. On the other hand, there are studies reporting that itraconazole prophylaxis had no effect on the molecular method used [76]. Therefore, sensitivity of molecular tests should also be interpreted with caution $[77,78]$.

\section{Prophylaxis Failure}

\section{Dr. Seçkin Çağırgan}

AFP failure may be defined as the development of proven or probable IFD during prophylaxis, the requirement of empirical antifungal treatment, and the necessity of discontinuing the prophylaxis drug due to side effects or patient-related reasons [39].

AFP failure due to development of an IFD may be related to the activity spectrum of the prophylactic agent, development of infection with resistant fungal pathogens, and failure to provide effective blood levels of the drug. Although fluconazole prophylaxis significantly reduces Candida infections in patients with acute myelocytic leukemia and in those undergoing allogeneic stem cell transplantation, it is accompanied with an increase in the rates of invasive aspergillosis and other mold infections, as fluconazole is not active against molds [39,42,44,79]. Moreover, it has been shown that fluconazole prophylaxis increases colonization and development of infection with resistant non-albicans Candida species [80,81]. The risk of aspergillosis decreases if a broadspectrum azole (itraconazole, voriconazole, or posaconazole) or an echinocandin effective against Aspergillus species is used; however, the probability of infections with other molds, especially Mucorales species, remains the same, as itraconazole, voriconazole, and echinocandins are not effective against Mucorales [82]. Failure in providing adequate serum levels is most frequently seen when using oral itraconazole and posaconazole and this may lead to prophylaxis failure and development of an IFD [2]. Particularly, patients with mucositis, nausea and vomiting, insufficient enteral intake, and diarrhea are at risk.

Necessity of termination of prophylaxis or switching to another drug may be associated with patient intolerance or drug toxicity. Gastrointestinal intolerance and hepatotoxicity are the most common toxicity-related causes of AFP termination [2].

Prophylaxis using mold active agents, posaconazole being the leading one, has been demonstrated to significantly decrease the sensitivity of galactomannan testing [83,84]. Therefore, a preemptive AFP treatment approach based on galactomannan antigen monitoring will not be safe in these patients; hence, an empirical treatment approach is recommended.

A detailed diagnostic study should be started in patients with prophylaxis failure if symptoms and clinical findings indicative of an IFD are present. If possible, the pathogen should be detected (microscopic examination in suitable samples, culture, histopathological examination; bronchoscopy, galactomannan testing in bronchoalveolar lavage fluid in the presence of a pulmonary lesion, etc.) [2].

Which antifungal agent should be selected in AFP failure characterized by IFD development or the requirement of initiating empirical fungal treatment? As a general rule, a change in the antifungal agent class should be considered if an IFD is suspected [2]. The majority of cases with prophylaxis failure are associated with the development of pulmonary infiltrates. During oral mold-active azole prophylaxis, switching to liposomal amphotericin B should be considered if aspergillosis is suspected (galactomannan positivity) and effective serum levels of itraconazole or posaconazole can be achieved or if drug level monitoring is not available [2,82]. If low serum levels of itraconazole or posaconazole have been shown, intravenous voriconazole can be used [2]. If galactomannan antigen testing is negative or is not available and a mold-active azole or echinocandin effective against Aspergillus strains has been used in prophylaxis, the risk of Aspergillus infection decreases; however, the probability 
of infections with other filamentous fungi, particularly Mucorales, remains, as itraconazole, voriconazole, and echinocandins are not effective against Mucorales strains. Posaconazole is active against some Mucorales strains; however, effective serum concentrations usually cannot be achieved. In these conditions, liposomal amphotericin B, with the widest spectrum of activity (Candida, Aspergillus species, Cryptococcus, Fusarium, Mucorales, and endemic fungi), is the antifungal drug that should be chosen.

Azoles should not be used empirically in the case of prior azole prophylaxis [58].

\section{Secondary Prophylaxis}

\section{Dr. Mehmet Ali Özcan}

During cytotoxic treatment, there is a substantial risk of recurrent invasive fungal infection in patients who "survived" the first invasive fungal infection. This rate is between $16 \%$ and $33 \%$ in the published series and IFD-related mortality reaches up to $88 \%[85,86,87,88,89]$. Application of antifungal drugs for the management of this risk is called "secondary prophylaxis". The most important problem in this area is that there is still no prospective randomized study on this subject.
Therefore, evaluations are based on available experiences with different applications of antifungal agents. Amphotericin formulations, fluconazole, itraconazole, caspofungin, voriconazole, and posaconazole can be used in secondary prophylaxis depending on the use and success of these agents in primary treatment [90] (Table 1). While secondary prophylaxis seems to be effective according to the information obtained from case series and the few prospective secondary prophylaxis studies published to date, sufficient evidence to make a recommendation on the use of "which agent", "what dose", and "for how long" has not yet been provided.

In manuscripts evaluating secondary prophylaxis, probable risk factors, mainly neutropenia duration, state of underlying disease, presence of GVHD, and steroid use, are found to be important.

The European Conference on Infections in Leukemia guidelines recommend secondary prophylaxis with an evidence level of AII, and, instead of recommending a certain agent, they recommend that secondary prophylaxis should be based on the causative agent of the prior invasive fungal infection and treatment success [58].

Table 1. Studies on secondary prophylaxis for invasive fungal diseases (IFDs).

\begin{tabular}{|c|c|c|c|c|c|}
\hline Source & Study & $\begin{array}{l}\text { The Numbers and } \\
\text { Characteristics of } \\
\text { the Patients }\end{array}$ & Drug & $\begin{array}{l}\text { Treatment } \\
\text { Duration }\end{array}$ & $\begin{array}{l}\text { New } \\
\text { Breakthrough } \\
\text { IFD }\end{array}$ \\
\hline $\begin{array}{l}\text { Sevilla et al. } \\
\text { [91] }\end{array}$ & Case series & 7 acute leukemia & $\begin{array}{l}\text { Itraconazole + liposomal } \\
\text { amphotericin }\end{array}$ & 4-22 months & $0 / 7$ \\
\hline $\begin{array}{l}\text { Nosari et al. } \\
{[92]}\end{array}$ & Case series & $\begin{array}{l}24 \text { patients; } 9 \text { patients } \\
\text { allo, } 15 \text { patients acute } \\
\text { leukemia }\end{array}$ & $\begin{array}{l}\text { Itraconazole; itracon- } \\
\text { azole + liposomal am- } \\
\text { photericin }\end{array}$ & Not indicated & $3 / 24$ \\
\hline $\begin{array}{l}\text { Krüger et al. } \\
\text { [93] }\end{array}$ & Case series & 43 allo & $\begin{array}{l}\text { Liposomal amphoteri- } \\
\text { cin B }\end{array}$ & 2-54 days & $0 / 43$ \\
\hline $\begin{array}{l}\text { Cornely et al. } \\
{[85]}\end{array}$ & $\begin{array}{l}\text { Prospective } \\
\text { survey }\end{array}$ & $\begin{array}{l}124 \text { patients, } 14.5 \% \\
\text { surgical resections }\end{array}$ & $\begin{array}{l}\text { Miscellaneous; } \\
\text { itraconazole, } \\
\text { voriconazole, liposomal } \\
\text { amphotericin }\end{array}$ & Not indicated & $26 / 124$ \\
\hline $\begin{array}{l}\text { Zhang et al. } \\
{[94]}\end{array}$ & Retrospective & $\begin{array}{l}49 \text { patients; } 25 \text { ALL, } \\
10 \text { AML }\end{array}$ & $\begin{array}{l}\text { Miscellaneous; } \\
\text { voriconazole, itracon- } \\
\text { azole, caspofungin, lipo- } \\
\text { somal amphotericin }\end{array}$ & Not indicated & $9 / 49$ \\
\hline $\begin{array}{l}\text { Cordonnier et } \\
\text { al. [95] }\end{array}$ & $\begin{array}{l}\text { Prospective } \\
\text { open }\end{array}$ & 45 patients & $\begin{array}{l}\text { Voriconazole, } 400 \text { mg/ } \\
\text { kg/day }\end{array}$ & 5-180 days & $2 / 45$ \\
\hline
\end{tabular}

IFD: Invasive fungal disease. 
In the decision-making period of secondary prophylaxis, the selected patients with sequel lesions are to be evaluated in terms of receiving chemotherapy or surgical resection before transplantation. As this group of patients is small in number in case series, it would be suitable to evaluate this subgroup separately in clinical studies.

\section{Environmental Protection}

\section{Dr. Can Boğa}

The basic principle in AFP is to use drugs with proven efficacy and high evidence levels. This section of the article mainly discusses subjects associated with environmental factors.

Table 2. Recommendations of the CDC and the Healthcare Infection Control Practices Advisory Committee (HICPAC) [100].

Recommendations for Increasing Air Quality

Evidence Level*

Use of heating, pressure, and ventilation filters

Environmental monitoring

Use of portable HEPA filters

Providing back-ups for technical problems such as power source

Obtaining tissue biopsies and culture samples for diagnosis, in case of Aspergillus or other respiratory nosocomial infection

Taking necessary preventive precautions during construction (barriers, stoppers, portable HEPA filters, etc.) Shortening the exposure time to fungal spores in transplant patients

Maintenance of preventive measures when the patients leave their rooms for interventional procedures

Maintaining positive pressure with respect to corridors

Patient must be placed in a protective environment room with an anteroom

Category $1 \mathrm{~B}$

Category $1 \mathrm{~B}$

Category 2

Category $1 \mathrm{C}$

Category $1 \mathrm{~B}$

Category $1 \mathrm{~B}$

Category $1 \mathrm{~B}$

Category $1 \mathrm{~B}$

Category $1 \mathrm{~B}$

Category $1 \mathrm{C}$

\section{Recommendations Related to Water Systems}

Prevention of damage to underground water pipes and contamination of water by soil

Elimination of contaminated reservoirs

Disinfection of sinks and taps

Use of barrier precautions (gloves) in order to prevent the spread of infection after hand-washing

Maintaining the temperature of hot water at $>51{ }^{\circ} \mathrm{C}$ and cold water at $<20^{\circ} \mathrm{C}$

Periodically increasing the temperature of water to at least $66^{\circ} \mathrm{C}$

Chlorination of water

Disinfection of water tanks

\section{Other Environmental Precautions}

Scrubbing the non-critical surfaces with detergents

Regular scrubbing of ceilings, floors, and walls

Not performing alcohol disinfestation on large surfaces

Use of registered ready-to-use disinfectants

Deep vacuum cleaning of the carpets and wool fabrics

Avoiding the use of carpets in high-traffic zones

Using carpeting in dry places (in order to avoid fungal growth), not keeping carpets in wet places for over $72 \mathrm{~h}$

Restriction of flowers

Staff should be instructed to wear gloves when handling plants and flowers; negative pressure should be provided in the areas with dirty laundry

Minimizing contact with saliva, urine, and feces of animals

Hand-washing after contact with an animal

Implementation of waste control procedures

Category $1 \mathrm{~B}$

Category $1 \mathrm{~B}$

Category 2

Category $1 \mathrm{~A}$

Category $1 \mathrm{C}$

Category 2

Category $1 \mathrm{C}$

Category 2

\footnotetext{
*: Good Manufacturing Practice recommendations are taken into account. Category 1A: Strongly recommended for implementation and strongly supported by well-designed experimental, clinical, or epidemiologic studies. Category 1B: Strongly recommended for implementation and supported by certain experimental, clinical, or epidemiologic studies and a strong theoretic rationale. Category lC: Required by state or federal regulation or representing an established association standard. Category 2: Suggested for implementation and supported by suggestive clinical or epidemiologic studies, or a theoretic rationale.
} 
Nosocomial fungal infections are mainly transmitted by air, and less frequently by the oral route. It is well known that hospital construction and repair activities may increase the fungal spore concentrations in the air and that they are associated with the frequency of IFDs [96,97].

Organizations That Recommend the Use of HEPA Filters in Critical Areas

Areas such as bone marrow transplantation units, in which immunosuppressed patients that require protection from infectious agents are monitored, and the isolation areas in which infected patients are monitored are defined as critical areas. The US Centers for Disease Control and Prevention (CDC) and the Spanish Society of Infectious Diseases and Clinical Microbiology recommend that these areas should be separated from other areas; heating, water systems, and ventilation conditions should be specially organized; and HEPA filters changing the room air 12 times in an hour should be used (Table 2) [98].

\section{In What Conditions Are HEPA Filters Effective?}

The minimum acceptable limits that can lead to the development of IFDs are debatable. It is required that HEPA filters should remove the respirable particles from the environment at least at the Good Manufacturing Practices Class D level (Table 3). It was demonstrated in a Spanish study that if the limit for the room air is $0.5 \mathrm{CFU} / \mathrm{m}^{3}$, or in other words if the presence of 1 fungus colony in $2 \mathrm{~m}^{3}$ of air is allowed, it can lead to infections in high-risk patients [97].

\section{Evaluations of the Outcomes of HEPA Filter Use}

The results of published studies on HEPA filters are summarized as follows [98,99,100,101,102,103,104,105]:

a. HEPA filters are effective to reduce the fungal load in the room air during and after construction.

b. HEPA filters were found to provide a more effective protection against invasive aspergillosis than amphotericin B during and after construction.

c. Acceleration of the laminar flow increases the efficacy of HEPA filters. Fungal concentration in the air is correlated with a decrease in IFD incidence.

Table 3. Clean room classification arranged according to the number of particles considering the particle size [100].

\begin{tabular}{l|l|l|} 
Class & $\begin{array}{l}\text { Particle Diameter } \\
(>0.5 \mu \mathrm{m})\end{array}$ & $\begin{array}{l}\text { Particle Diameter } \\
(>5 \mu \mathrm{m})\end{array}$ \\
\hline A & 3520 & 20 \\
B & 35,200 & 29 \\
\hline C & 352,000 & 2900 \\
D & $3,520,000$ & 29,000 \\
\hline
\end{tabular}

d. Moreover, HEPA filters were shown to improve the general quality of life after transplantation.

\section{The Efficacy of Portable HEPA Filters}

The CDC recommends the use of portable HEPA filters with rates of 300-800 cubic feet per minute to improve the removal process of respirable particles (Category 2). HEPA filters may be placed at different locations in and out of the room during and after construction until the surfaces are completely cleaned (Category 2). Microbiological analysis of the air samples during and immediately after construction is not recommended $[98,99,100]$.

\section{Problematic Issues}

Issues like patient-related comorbid conditions, the degree of immunosuppression, AFP, and microbiological quality of the water make it difficult to make scientific inferences. It has been reported that the gravity air-setting plate method is an applicable method in aerobiological monitoring of fungal spores. Petri plates involving Sabouraud agar media are placed in different areas of the rooms for $1 \mathrm{~h}$ with their lids open and each test is repeated 3 times. The samples are kept at $37^{\circ} \mathrm{C}$ for 7 days.

\section{Quality Control}

The necessary protective precautions during transfer of the patients, primarily the hand-washing of the health care staff, and the necessary arrangements in terms of hygiene, waste control, and biosafety increase the efficacy of environmental control.

\section{Antifungal Vaccines \\ Dr. Zahit Bolaman}

Aggressive chemotherapy or the use of agents leading to lymphocyte dysfunction such as rituximab and Campath and GVHD-related immunosuppression negatively affect the previous immunity achieved by vaccines in hematological malignant diseases [106]. As therisk forpneumococcalinfection increases, patients are recommended to receive pneumococcal conjugate (PCV13) vaccine or pneumococcal polysaccharide vaccine (PPV23) before or during chemotherapy [107]. For inactivated influenza, hepatitis A, hepatitis B, meningococcus, conjugate haemophilus influenza, diphtheria-tetanuspertussis, human papilloma, and poliovirus vaccinations, the country's vaccination program is taken into account. It is not recommended that acute leukemia patients under induction, consolidation, or maintenance treatment or those receiving rituximab or alemtuzumab be vaccinated with any vaccine other than pneumococcal vaccine. Live vaccines including measles-mumps-scarlet fever, shingles, chicken pox, and polio are contraindicated before or during chemotherapy [108].

The immune system is reorganized after allogeneic stem cell transplantation. Vaccination with PCV13 or PPV23, inactivated 
Table 4. Immunological properties of fungal vaccines.

\begin{tabular}{|c|c|c|}
\hline Disease & Vaccine & Mechanism \\
\hline Aspergillosis & $\begin{array}{l}\text { HKY (heat-killed S. cerevisiae cells)* } \\
\text { Laminarin-CRM197 conjugate* } \\
\text { AspF antigens } \\
\text { Cell-wall glucanase Crf1* }\end{array}$ & $\begin{array}{l}\text { Incomplete information: Possibly related to } \\
\text { the antifungal effect of protective CD4Th1 } \\
\text { antibodies }\end{array}$ \\
\hline Candida & $\begin{array}{l}\text { Laminarin } \\
\text { Fba (fructose-biphosphate-aldolase)* } \\
\beta \text {-Mannan-peptide or protein conju- } \\
\text { gates } \\
\text { Candida albicans cell-surface protein } \\
\text { HyR1* } \\
\text { Recombinant Als3* proteins* } \\
\text { Recombinant Sap2* proteins } \\
\text { Laminarin-CRM197 conjugate } \\
\text { Mdh-1p }\end{array}$ & $\begin{array}{l}\text { Direct antifungal effect of CD4Thl antibod- } \\
\text { ies } \\
\text { Direct effect of anti-fba antibodies } \\
\text { Opsonic, antibody-mediated } \\
\text { Anti-Hyrlp neutralizing antibodies } \\
\text { Antibodies developed due to Th17-Th1 } \\
\text { activity } \\
\text { Antibodies neutralizing Sap activity } \\
\text { Direct anti-Candida effect of anti- } \beta \text {-glucan } \\
\text { antibody } \\
\text { Anti-Mdh-1p antibody }\end{array}$ \\
\hline Cryptococcus & $\begin{array}{l}\text { Laminarin-CRM197 conjugate } \\
\text { GXM conjugate peptide mimotopes }\end{array}$ & $\begin{array}{l}\text { Antibodies related to capsule structure and } \\
\text { function } \\
\text { Opsonic anti-capsular antibodies } \\
* \text { : Universal. }\end{array}$ \\
\hline
\end{tabular}

influenza, hepatitis A and B, conjugate haemophilus influenza $\mathrm{B}$, diphtheria-tetanus-pertussis, conjugate meningococcus, or inactivated polio is recommended to be performed at 3-12 months after transplantation. General rules apply for the human papilloma virus vaccine. Live measles-mumps-scarlet fever vaccine is applied if the patient is seronegative, does not have GVHD, and is not receiving immunosuppressive treatment. Attenuated live influenza, live measles, mumps and measles-varicella, BCG, live shingles, varicella, and shingles vaccines are contraindicated (Table 4, Figure 1). Data are insufficient for typhoid fever and cholera vaccines $[60,108,109,110]$.

The aggressive therapiesused in hematological malignancies cause tissue destruction and immunosuppression, sometimes resulting in death due to fungal infections. Although some patients benefit from antifungal prophylaxis, the results are not very satisfying and optimal antifungal treatment strategies can only rescue $50 \%$ of patients. This is also associated with high economic cost. As a result, novel approaches are needed. Antifungal vaccines are developed for this purpose and show their effect by stimulating humoral or cellular immunity and by dendritic cells. For the full-blown effect of an antifungal vaccine, it is important to develop them against common fungal antigens (universal vaccines) [111]. The targeted antifungal determinants and their mechanisms are shown in Table 4. Successful results have been achieved in animal

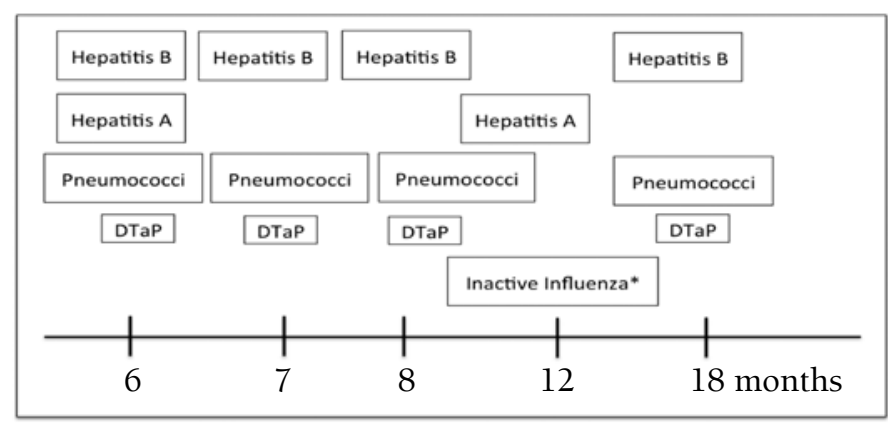

Figure 1. Vaccination program after allogeneic stem cell transplantation (modified from the Report from the International Consensus Conference on Clinical Practice in Chronic Graft-versus-host disease) [110].

DTaP: Diphtheria-tetanus-attenuated pertussis vaccine

*Influenza vaccine is repeated each year.

studies on fungal cell determinants, mainly laminarin, cell surface antigen, or dendritic cell-mediated vaccination [112]. Experimental animal studies are on-going with vaccines developed against Aspergillus, Candida, Cryptococcus, and pneumocystis infections, and 3 studies are being carried out in humans on recombinant NDV-3. Although lack of standardization, reduced immunogenicity, and difficulties in the vaccination of immunosuppressive individuals reduce the development speed of fungal vaccines, initial studies are 
Table 5. Pros and cons of antifungal prophylaxis.

\section{Advantages of antifungal prophylaxis}

The prevalence of IFD caused by Candida strains has been decreased with routine AFP.

The patients who will benefit from AFP can depend on the right classification of risk groups.

There are many old and new drugs with proven efficacy that can be used in AFP.

AFP has been shown to be beneficial in some high-risk patients with hematological malignancies or in those undergoing stem cell transplantation.

Different drugs should be selected in patients according to the increased risk of developing yeast or mold infections.

\section{Problems with antifungal prophylaxis}

There has been an increase in the prevalence of Aspergillus and non-albicans Candida strains with routine AFP. In particular, mucormycosis frequency has been shown to increase with broadspectrum azole prophylaxis [115,116].

Risk factors and potentials for developing diseases are widely variable. Patients should be assessed individually for multiple factors; there are differences in the risk factors and classifications over time.

The usage, doses, efficacies, and side effect profiles of these drugs are quite different from each other.

In these patients, the frequently used drugs, mainly chemotherapy and immunosuppressive drugs, interact with many other drugs.

Food may change the absorption rates of the drugs and there may be individual differences.

Low IFD incidence in certain patient groups, increased risk of toxicity and resistance, and increased treatment cost due to unnecessary AFP use prevents its routine use in all patients. Patientbased risk-benefit evaluation should be performed.

The number of randomized controlled trials (RCTs) in which headto-head comparisons of several drugs are made is limited. Therefore, recommendations with high levels of evidence cannot be made in various guidelines and different recommendations are available in different guidelines. Treatment failure rates with mold-active AFP in real-life studies are higher in comparison to those in registration studies [116,117,118,119].

Meta-analysis performed in 2007 [11]:

64 RCTs, AFP (fluconazole, itraconazole, posaconazole) versus placebo

No difference could be detected in all-cause mortality (RR: 0.88 ) in acute leukemia patients.

Meta-analysis performed in 2012 [53]:

20 RCTs, mold-active versus fluconazole

No difference could be detected in all-cause mortality in acute leukemia and allogeneic transplant patients. Side effects leading to drug discontinuation were more common in patients using moldactive drugs (RR: 1.95). 
Table 5. Continuous

\section{Advantages of Antifungal prophylaxis}

Meta-analysis performed in 2014 [120]:

20 RCTs, stem cell transplantations

Risk of documented fungal disease (OR: 0.24), risk of systemic candidiasis (OR: 0.11), and overall need for empirical antifungal treatment (OR: 0.60) was decreased in patients receiving fluconazole in comparison to those receiving a placebo.

Risk of invasive aspergillosis was lower in patients receiving itraconazole than in those receiving fluconazole (OR: 0.40). Risk of mold infections was found to be lower in those receiving micafungin than those receiving fluconazole (OR: $0.35)$

Voriconazole was found to be superior to fluconazole and itraconazole, and posaconazole was found to be superior to amphotericin B.

GITMO guidelines published in 2014 [121]:

Allogeneic stem cell transplantation patients are divided into 3 risk groups (high, standard, low) in 3 different periods (early, late, very late). Mold-active drugs are recommended in the high-risk group, and AFP is recommended in the standard-risk group.

Fluconazole:

Oral +4 , cheap, good tolerability, fewer drug interactions

\section{Echinocandin group:}

Effective against most Candida species, safety profile is high and drug interaction is low.

Itraconazole:

Effective against Aspergillus spp.

Voriconazole:

Oral +4 , wide spectrum of activity, superior to fluconazole and itraconazole in AFP.

Posaconazole:

Oral +4 , wide spectrum of activity

Liposomal amphotericin B:

A single high dose once a week, effective and safe in AML patients and children.

\section{Drug level monitoring:}

Used to increase treatment success and decrease side effects, is recommended for mold-active drugs (itraconazole, voriconazole, and posaconazole)

\section{Timing of AFP:}

AFP drugs that carry a risk of interaction with chemotherapy drugs are recommended to be discontinued 1 week before chemotherapy and initiated after termination of chemotherapy. If not receiving AFP is a risk for the patient, echinocandin-group drugs or liposomal amphotericin B may be given in this period.

Interaction with diagnostic antigen tests:

Drugs do not affect standardized PCR-based tests.

\section{Secondary AFP:}

The drug that is effective in the treatment of the first attack should be preferred.

\section{Problems with antifungal prophylaxis}

\section{Meta-analysis performed in 2014 [120]:}

20 RCTs, stem cell transplantations

IFD risk under AFP was 5.1\%.

Most of the studies were performed using fluconazole.

Comparative studies with new azoles are very limited (a single RCT).

\section{Real-life data published in recent years [117]:}

Posaconazole comes into prominence in AML and MDS patients and in transplant patients with GVHD; although the level of evidence is low as the studies were retrospective and comparisons were made with historic controls, these data are valuable as they reflect real life.

\section{Fluconazole:}

Anti-Candida spectrum is narrower than the candins, there is a risk of breakthrough infections (C. krusei, C. glabrata), not effective against molds.

Echinocandin group:

Can only be used by 4 route, expensive.

Itraconazole:

Can only be used by oral route, low tolerability, variable bioavailability, high drug interactions.

Voriconazole:

May lead to temporary visual impairment and hepatic toxicity, may interact with chemotherapy drugs.

Posaconazole:

Oral bioavailability is variable, may interact with chemotherapy drugs and proton pump inhibitors.

Liposomal amphotericin B:

Studies involving small series.

Drug level monitoring:

Not in routine use in guidelines yet.

\section{Timing of AFP:}

There is no clear standard on this issue; it may be necessary to continue it until neutrophil counts exceed $500 / \mathrm{mm}^{3}$ in leukemia patients and for at least 3 months in allogeneic transplants. If the patient is still at risk (immunosuppressive treatment, etc.), the period should be prolonged.

\section{Interaction with diagnostic antigen tests:}

Mold-active drugs (posaconazole, voriconazole) decrease the sensitivity of galactomannan test.

Secondary AFP:

Risk of IFD extensively increases in the other chemotherapy periods of patients that had a previous IFD.

IFD: Invasive fungal disease, AFP: antifungal prophylaxis, GVHD: Graft-versus-host disease, AML: acute myeloid leukemia, MDS: myelodysplastic syndrome. 
promising in decreasing deaths related to fungal infections by fungal vaccinations in the future $[112,113,114]$.

\section{Interpretation and Problematic Areas \\ Dr. İhsan Karadoğan}

Although prophylaxis in IFDs has become more evidencebased in recent years, there are still several gray areas and unresolved issues. A summary of these issues is presented in Table 5.

\section{Conflict of Interest Statement}

The authors of this paper have no conflicts of interest, including specific financial interests, relationships, and/or affiliations relevant to the subject matter or materials included.

\section{References}

1. Pagano L, Akova M, Dimopoulos G, Herbrecht R, Drgona L, Blijlevens N. Risk assessment and prognostic factors for mould-related diseases in immunocompromised patients. J Antimicrob Chemother 2011;66(Suppl 1):i5-14.

2. Akan H, Antia VP, Kouba M, Sinko J, Tanase AD, Vrhovac R, Herbrecht R. Preventing invasive fungal disease in patients with haematological malignancies and the recipients of haematopoietic stem cell transplantation: practical aspects. J Antimicrob Chemother 2013;68(Suppl 3):iii5-16.

3. Donnelly JP. Where are we with antifungal prophylaxis in AML and allogeneic HSCT? In: ESCMID Online Lecture Library. Available online at http://www.escmid.org/escmid_ library/online_lecture_library/material/?mid=2429.

4. Drgona L, Colita A, Klimko N, Rahav G, Ozcan MA, DonnellyJP. Triggers for driving treatment of at-risk patients with invasive fungal disease. J Antimicrob Chemother 2013;68(Suppl 3):iiil7-24.

5. Pagano L, Caira M, Candoni A, Offidani M, Fianchi L, Martino B, Pastore D, Picardi M, Bonini A, Chierichini A, Fanci R, Caramatti C, Invernizzi R, Mattei D, Mitra ME, Melillo L, Aversa F, Van Lint MT, Falcucci P, Valentini CG, Girmenia C, Nosari A. The epidemiology of fungal infections in patients with hematologic malignancies: the SEIFEM-2004 study. Haematologica 2006;91:1068-1075.

6. Kontoyiannis DP, Marr KA, Park BJ, Alexander BD, Anaissie EJ, Walsh TJ, Ito J, Andes DR, Baddley JW, Brown JM, Brumble LM, Freifeld AG, Hadley S, Herwaldt LA, Kauffman CA, Knapp K, Lyon GM, Morrison VA, Papanicolaou G, Patterson TF, Perl TM, Schuster MG, Walker R, Wannemuehler KA, Wingard JR, Chiller TM, Pappas PG. Prospective surveillance for invasive fungal infections in hematopoietic stem cell transplant recipients, 2001-2006: overview of the Transplant-Associated Infection Surveillance Network (TRANSNET) Database. Clin Infect Dis 2010;50:1091-1100.
7. Pizzo PA, Robichaud KJ, Gill FA, Witebsky FG. Empiric antibiotic and antifungal therapy for cancer patients with prolonged fever and granulocytopenia. Am J Med 1982;72:101-111.

8. [No authors listed.] Empiric antifungal therapy in febrile granulocytopenic patients. EORTC International Antimicrobial Therapy Cooperative Group. Am J Med 1989;86(6 Pt 1):668672.

9. Morrell M, Fraser VJ, Kollef MH. Delaying the empiric treatment of Candida bloodstream infection until positive blood culture results are obtained: a potential risk factor for hospital mortality. Antimicrob Agents Chemother 2005;49:3640-3645.

10. Hachem R, Sumoza D, Hanna H, Girgawy E, Munsell M, Raad I. Clinical and radiologic predictors of invasive pulmonary aspergillosis in cancer patients: should the European Organization for Research and Treatment of Cancer/Mycosis Study Group (EORTC/MSG) criteria be revised? Cancer 2006;106:1581-1586.

11. Robenshtok E, Gafter-Gvili A, Goldberg E, Weinberger M, Yeshurun M, Leibovici L, Paul M. Antifungal prophylaxis in cancer patients after chemotherapy or hematopoietic stemcell transplantation: systematic review and meta-analysis. J Clin Oncol 2007;25:5471-5489.

12. Worth LJ, Slavin MA. Bloodstream infections in haematology: risks and new challenges for prevention. Blood Rev 2009;23:113-122.

13. Zhang P, Jiang EL, Yang DL, Yan ZS, Huang Y, Wei JL, Wang M, Ma QL, Liu QG, Zou DH, He Y, Qiu LG, Feng SZ, Han MZ. Risk factors and prognosis of invasive fungal infections in allogeneic stem cell transplantation recipients: a singleinstitution experience. Transpl Infect Dis 2010;12:316-321.

14. Martino R, Subira M. Invasive fungal infections in hematology: new trends. Ann Hematol 2002;81:233-243.

15. Rickerts V, Bohme A, Just-Nubling G. Risk factor for invasive zygomycosis in patients with hematologic malignancies. Mycoses 2002;45(Suppl 1):27-30.

16. Buckley SA, Othus M, Vainstein V, Abkowitz JL, Estey EH, Walter RB. Prediction of adverse events during intensive induction chemotherapy for acute myeloid leukemia or high-grade myelodysplastic syndromes. Am J Hematol 2014;89:423-428.

17. Wingard JR, Hsu J, Hiemenz JW. Hematopoietic stem cell transplantation: an overview of infection risks and epidemiology. Hematol Oncol Clin North Am 2011;25:101-116.

18. Montagna MT, De Giglio O, Napoli C, Lovero G, Caggiano G, Delia M, Pastore D, Santoro N, Specchia G. Invasive fungal infections in patients with hematologic malignancies (Aurora Project): lights and shadows during 18-months surveillance. Int J Mol Sci 2012;13:774-787. 
19. Martino R, Subira M, Rovira M, Solano C, Vazquez L, Sanz GF, Urbano-Ispizua A, Brunet S, De la Camara R; alloPBSCT Infectious/Non-infectious Complications Subcommittees of the Grupo Español de Trasplante Hematopoyético (GETH). Invasive fungal infections after allogeneic peripheral blood stem cell transplantation: incidence and risk factors in 395 patients. Br J Haematol 2002;116:475-482.

20. Garcia-Vidal C, Upton A, Kirby KA, Marr KA. Epidemiology of invasive mold infections in allogeneic stem cell transplant recipients: biological risk factors for infection according to time after transplantation. Clin Infect Dis 2008;47:10411050.

21. Marr KA, Carter RA, Boeckh M, Martin P, Corey L. Invasive aspergillosis in allogeneic stem cell transplant recipients: changes in epidemiology and risk factors. Blood 2002;100:4358-4366.

22. Omer AK, Ziakas PD, Anagnostou T, Coughlin E, Kourkoumpetis T, McAfee SL, Dey BR, Attar E, Chen YB, Spitzer TR, Mylonakis E, Ballen KK. Risk factors for invasive fungal disease after allogeneic hematopoietic stem cell transplantation: a single center experience. Biol Blood Marrow Transplant 2013;19:1190-1196.

23. Sun Y, Xu L, Liu D, Zhang X, Han W, Wang Y, Chen H, Chen Y, Wang F, Wang J, Ji Y, Tang F, Liu K, Huang XJ. Incidence of invasive fungal disease after unmanipulated haploidentical stem cell transplantation was significantly higher than that after HLA-matched sibling transplantation. Clin Microbiol Infect 201319:1029-1034.

24. Sun YQ, Xu LP, Liu DH, Zhang XH, Chen YH, Chen H, Ji Y, Wang Y, Han W, Wang JZ, Wang FR, Liu KY, Huang XJ. The incidence and risk factors of invasive fungal infection after haploidentical haematopoietic stem cell transplantation without in vitro T-cell depletion. Clin Microbiol Infect 2012;18:997-1003.

25. Li L, Wang J, Zhang W, Yang J, Chen L, Lv S. Risk factors for invasive mold infections following allogeneic hematopoietic stem cell transplantation: a single center study of 190 recipients. Scand J Infect Dis 2012;44:100-107.

26. Gerson SL, Talbot GH, Hurwitz S, Strom BL, Lusk EJ, Cassileth PA. Prolonged granulocytopenia: the major risk factor for invasive pulmonary aspergillosis in patients with acute leukemia. Ann Intern Med 1984;100:345-351.

27. Portugal RD, Garnica M, Nucci M. Index to predict invasive mold infection in high-risk neutropenic patients based on the area over the neutrophil curve. J Clin Oncol 2009;27:38493854.

28. Camargo JF, Husain S. Immune correlates of protection in human invasive aspergillosis. Clin Infect Dis 2014;59:569577.

29. Bochud PY, Chien JW, Marr KA, Leisenring WM, Upton A, Janer M, Rodrigues SD, Li S, Hansen JA, Zhao LP, Aderem
A, Boeckh M. Toll-like receptor 4 polymorphisms and aspergillosis in stem-cell transplantation. N Engl J Med 2008;359:1766-1777.

30. Zaas AK, Liao G, Chien JW, Weinberg C, Shore D, Giles SS, Marr KA, Usuka J, Burch LH, Perera L, Perfect JR, Peltz G, Schwartz DA. Plasminogen alleles influence susceptibility to invasive aspergillosis. PLoS Genet 2008;4:e1000101.

31. Chai LY, de Boer MG, van der Velden WJ, Plantinga TS, van Spriel AB, Jacobs C, Halkes CJ, Vonk AG, Blijlevens NM, van Dissel JT, Donnelly PJ, Kullberg BJ, Maertens J, Netea MG. The Y238X stop codon polymorphism in the human beta-glucan receptor dectin-1 and susceptibility to invasive aspergillosis. J Infect Dis 2011;203:736-743.

32. Cunha C, Rodrigues F, Zelante T, Aversa F, Romani L, Carvalho A. Genetic susceptibility to aspergillosis in allogeneic stemcell transplantation. Med Mycol 2011;49(Suppl 1):S137143.

33. Loeffler J, Ok M, Morton OC, Mezger M, Einsele H. Genetic polymorphisms in the cytokine and chemokine system: their possible importance in allogeneic stem cell transplantation. Curr Top Microbiol Immunol 2010;341:83-96.

34. Cunha C, Aversa F, Lacerda JF, Busca A, Kurzai O, Grube M, Loffler J, Maertens JA, Bell AS, Inforzato A, Barbati E, Almeida B, Santos e Sousa P, Barbui A, Potenza L, Caira M, Rodrigues F, Salvatori G, Pagano L, Luppi M, Mantovani A, Velardi A, Romani L, Carvalho A. Genetic PTX3 deficiency and aspergillosis in stem-cell transplantation. N Engl J Med 2014;370:421-432.

35. Panackal AA, Li H, Kontoyiannis DP, Mori M, Perego CA, Boeckh M, Marr KA. Geoclimatic influences on invasive aspergillosis after hematopoietic stem cell transplantation. Clin Infect Dis 2010;50:1588-1597.

36. Blum G, Eschertzhuber S, Auberger J, Ulmer H, Geltner C, Gastl G, Nachbaur D, Lass-Florl C. Airborne fungus exposure prior to hospitalisation as risk factor for mould infections in immunocompromised patients. Mycoses 2012;55:237-243.

37. Munoz P, Burillo A, Bouza E. Environmental surveillance and other control measures in the prevention of nosocomial fungal infections. Clin Microbiol Infect 2001;7(Suppl 2):38-45.

38. Ullmann AJ, Lipton JH, Vesole DH, Chandrasekar P, Langston A, Tarantolo SR, Greinix H, Morais de Azevedo W, Reddy V, Boparai N, Pedicone L, Patino H, Durrant S. Posaconazole or fluconazole for prophylaxis in severe graft-versus-host disease. N Engl J Med 2007;356:335-347.

39. Cornely OA, Maertens J, Winston DJ, Perfect J, Ullmann AJ, Walsh TJ, Helfgott D, Holowiecki J, Stockelberg D, Goh YT, Petrini M, Hardalo C, Suresh R, Angulo-Gonzalez D. Posaconazole vs. fluconazole or itraconazole prophylaxis in patients with neutropenia. N Engl J Med 2007;356:348-359.

40. Theuretzbacher U, Ihle F, Derendorf H. Pharmacokinetic/ pharmacodynamic profile of voriconazole. Clin Pharmacokinet 2006;45:649-663. 
41. Krishna G, Martinho M, Chandrasekar P, Ullmann AJ, Patino $\mathrm{H}$. Pharmacokinetics of oral posaconazole in allogeneic hematopoietic stem cell transplant recipients with graftversus-host disease. Pharmacotherapy 2007;27:1627-1636.

42. Marr KA, Seidel K, Slavin MA, Bowden RA, Schoch HG, Flowers ME, Corey L, Boeckh M. Prolonged fluconazole prophylaxis is associated with persistent protection against candidiasis-related death in allogeneic marrow transplant recipients: long-term follow-up of a randomized, placebocontrolled trial. Blood 2000;96:2055-2061.

43. Slavin MA, Heath CH, Thursky KA, Morrissey CO, Szer J, Ling LM, Milliken ST, Grigg AP. Antifungal prophylaxis in adult stem cell transplantation and haematological malignancy. Intern Med J 2008;38:468-476.

44. Slavin MA, Osborne B, Adams R, Levenstein MJ, Schoch HG, Feldman AR, Meyers JD, Bowden RA. Efficacy and safety of fluconazole prophylaxis for fungal infections after marrow transplantation--a prospective, randomized, double-blind study. J Infect Dis 1995;171:1545-1552.

45. Goodman JL, Winston DJ, Greenfield RA, Chandrasekar PH, Fox B, Kaizer H, Shadduck RK, Shea TC, Stiff P, Friedman DJ, Powderly WG, Silber JL, Horowitz H, Lichtin A, Wolff SN, Mangan KF, Silver SM, Weisdorf D, Ho WG, Gilbert G, Buell D. A controlled trial of fluconazole to prevent fungal infections in patients undergoing bone marrow transplantation. $\mathrm{N}$ Engl J Med 1992;326:845-851.

46. Marr KA, Crippa F, Leisenring W, Hoyle M, Boeckh M, Balajee SA, Nichols WG, Musher B, Corey L. Itraconazole versus fluconazole for prevention of fungal infections in patients receiving allogeneic stem cell transplants. Blood 2004;103:1527-1533.

47. Wingard JR, Carter SL, Walsh TJ, Kurtzberg J, Small TN, Baden LR, Gersten ID, Mendizabal AM, Leather HL, Confer DL, Maziarz RT, Stadtmauer EA, Bolanos-Meade J, Brown J, Dipersio JF, Boeckh M, Marr KA; Blood and Marrow Transplant Clinical Trials Network. Randomized, doubleblind trial of fluconazole versus voriconazole for prevention of invasive fungal infection after allogeneic hematopoietic cell transplantation. Blood 2010;116:5111-5118.

48. Nucci M, Biasoli I, Akiti T, Silveira F, Solza C, Barreiros G, Spector N, Derossi A, Pulcheri W. A double-blind, randomized, placebo-controlled trial of itraconazole capsules as antifungal prophylaxis for neutropenic patients. Clin Infect Dis 2000;30:300-305.

49. Mattiuzzi GN, Cortes J, Alvarado G, Verstovsek S, Koller C, Pierce S, Blamble D, Faderl S, Xiao L, Hernandez M, Kantarjian H. Efficacy and safety of intravenous voriconazole and intravenous itraconazole for antifungal prophylaxis in patients with acute myelogenous leukemia or highrisk myelodysplastic syndrome. Support Care Cancer 2011;19:19-26.
50. Penack O, Schwartz S, Martus P, Reinwald M, Schmidt-Hieber M, Thiel E, Blau IW. Low-dose liposomal amphotericin B in the prevention of invasive fungal infections in patients with prolonged neutropenia: results from a randomized, singlecenter trial. Ann Oncol 2006;17:1306-1312.

51. Perfect JR, Klotman ME, Gilbert CC, Crawford DD, Rosner GL, Wright KA, Peters WP. Prophylactic intravenous amphotericin B in neutropenic autologous bone marrow transplant recipients. J Infect Dis 1992;165:891-897.

52. van Burik JA, Ratanatharathorn V, Stepan DE, Miller CB, Lipton JH, Vesole DH, Bunin N, Wall DA, Hiemenz JW, Satoi Y, Lee JM, Walsh TJ; National Institute of Allergy and Infectious Diseases Mycoses Study Group. Micafungin versus fluconazole for prophylaxis against invasive fungal infections during neutropenia in patients undergoing hematopoietic stem cell transplantation. Clin Infect Dis 2004;39:14071416.

53. Ethier MC, Science M, Beyene J, Briel M, Lehrnbecher T, Sung L. Mould-active compared with fluconazole prophylaxis to prevent invasive fungal diseases in cancer patients receiving chemotherapy or haematopoietic stem-cell transplantation: a systematic review and meta-analysis of randomised controlled trials. Br J Cancer 2012;106:1626-1637.

54. Vazquez L, Carreras E, Serrano D, Jarque I, Mensa J, Barberan J. Antifungal prophylaxis in the haematological patient: a practical approach. Rev Esp Quimioter 2012;25:299-304.

55. Rogers TR, Slavin MA, Donnelly JP. Antifungal prophylaxis during treatment for haematological malignancies: are we there yet? Br J Haematol 2011;153:681-697.

56. Cornely OA, Aversa F, Cook P, Jones B, Michallet M, Shea $\mathrm{T}$, Vallejo $\mathrm{C}$. Evaluating the role of prophylaxis in the management of invasive fungal infections in patients with hematologic malignancy. Eur J Haematol 2011;87:289-301.

57. Nucci M. Use of antifungal drugs in hematology. Rev Bras Hematol Hemoter 2012;34:383-391.

58. Maertens J, Marchetti O, Herbrecht R, Cornely OA, Flückiger U, Frêre P, Gachot B, Heinz WJ, Lass-Flörl C, Ribaud P, Thiebaut A, Cordonnier C; Third European Conference on Infections in Leukemia. European guidelines for antifungal management in leukemia and hematopoietic stem cell transplant recipients: summary of the ECIL 3--2009 update. Bone Marrow Transplant 2011;46:709-718.

59. Walsh TJ, Anaissie EJ, Denning DW, Herbrecht R, Kontoyiannis DP, Marr KA, Morrison VA, Segal BH, Steinbach WJ, Stevens DA, van Burik JA, Wingard JR, Patterson TF; Infectious Diseases Society of America. Treatment of aspergillosis: clinical practice guidelines of the Infectious Diseases Society of America. Clin Infect Dis 2008;46:327-360. 
60. Tomblyn M, Chiller T, Einsele H, Gress R, Sepkowitz K, Storek J, Wingard JR, Young JA, Boeckh MJ; Center for International Blood and Marrow Research; National Marrow Donor program; European Blood and Marrow Transplant Group; American Society of Blood and Marrow Transplantation; Canadian Blood and Marrow Transplant Group; Infectious Diseases Society of America; Society for Healthcare Epidemiology of America; Association of Medical Microbiology and Infectious Disease Canada; Centers for Disease Control and Prevention. Guidelines for preventing infectious complications among hematopoietic cell transplantation recipients: a global perspective. Biol Blood Marrow Transplant 2009;15:1143-1238.

61. Agrawal S, Hope W, Sinko J, Kibbler C. Optimizing management of invasive mould diseases. J Antimicrob Chemother 2011;66(Suppl 1):i45-53.

62. Maertens J, Groll AH, Cordonnier C, de la Camara R, Roilides E, Marchetti O. Treatment and timing in invasive mould disease. J Antimicrob Chemother 2011;66(Suppl 1):i37-43.

63. Ashbee HR, Barnes RA, Johnson EM, Richardson MD, Gorton R, Hope WW. Therapeutic drug monitoring (TDM) of antifungal agents: guidelines from the British Society for Medical Mycology. J Antimicrob Chemother 2014;69:11621176.

64. Cronin S, Chandrasekar PH. Safety of triazole antifungal drugs in patients with cancer. J Antimicrob Chemother 2010;65:410-416.

65. Moriyama B, Henning SA, Leung J, Falade-Nwulia O, Jarosinski P, Penzak SR, Walsh TJ. Adverse interactions between antifungal azoles and vincristine: review and analysis of cases. Mycoses 2012;55:290-297.

66. Girois SB, Chapuis F, Decullier E, Revol BG. Adverse effects of antifungal therapies in invasive fungal infections: review and meta-analysis. Eur J Clin Microbiol Infect Dis 2006;25:138149.

67. Glasmacher A, Prentice A, Gorschluter M, Engelhart S, Hahn C, Djulbegovic B, Schmidt-Wolf IG. Itraconazole prevents invasive fungal infections in neutropenic patients treated for hematologic malignancies: evidence from a meta-analysis of 3,597 patients. J Clin Oncol 2003;21:4615-4626.

68. Lestner JM, Roberts SA, Moore CB, Howard SJ, Denning DW, Hope WW. Toxicodynamics of itraconazole: implications for therapeutic drug monitoring. Clin Infect Dis 2009;49:928930.

69. Park WB, Kim NH, Kim KH, Lee SH, Nam WS, Yoon SH, Song KH, Choe PG, Kim NJ, Jang IJ, Oh MD, Yu KS. The effect of therapeutic drug monitoring on safety and efficacy of voriconazole in invasive fungal infections: a randomized controlled trial. Clin Infect Dis 2012;55:1080-1087.

70. Matsumoto K, Ikawa K, Abematsu K, Fukunaga N, Nishida K, Fukamizu T, Shimodozono Y, Morikawa N, Takeda Y,
Yamada K. Correlation between voriconazole trough plasma concentration and hepatotoxicity in patients with different CYP2C19 genotypes. Int J Antimicrob Agents 2009;34:9194.

71. Eiden C, Meniane JC, Peyriere H, Eymard-Duvernay S, Le Falher G, Ceballos P, Fegueux N, Cociglio M, Reynes J, Hillaire-Buys D. Therapeutic drug monitoring of posaconazole in hematology adults under posaconazole prophylaxis: influence of food intake. Eur J Clin Microbiol Infect Dis 2012;31:161-167.

72. Ananda-Rajah MR, Grigg A, Slavin MA. Making sense of posaconazole therapeutic drug monitoring: a practical approach. Curr Opin Infect Dis 2012;25:605-611.

73. Campoli P, Al Abdallah Q, Robitaille R, Solis NV, Fielhaber JA, Kristof AS, Laverdiere M, Filler SG, Sheppard DC. Concentration of antifungal agents within host cell membranes: a new paradigm governing the efficacy of prophylaxis. Antimicrob Agents Chemother 2011;55:57325739.

74. Marchetti O, Lamoth F, Mikulska M, Viscoli C, Verweij P, Bretagne S; European Conference on Infections in Leukemia (ECIL) Laboratory Working Groups. ECIL recommendations for the use of biological markers for the diagnosis of invasive fungal diseases in leukemic patients and hematopoietic SCT recipients. Bone Marrow Transplant 2012;47:846-854.

75. Reinwald M, Spiess B, Heinz WJ, Vehreschild JJ, Lass-Flörl C, Kiehl M, Schultheis B, Krause SW, Wolf HH, Bertz H, Maschmeyer G, Hofmann WK, Buchheidt D. Diagnosing pulmonary aspergillosis in patients with hematological malignancies: a multicenter prospective evaluation of an Aspergillus PCR assay and a galactomannan ELISA in bronchoalveolar lavage samples. Eur J Haematol 2012;89:120127.

76. Meije Y, Aguado JM, Cuenca-Estrella M. Silent and prolonged Aspergillus DNAemia in oncohematological patients receiving antifungal prophylaxis: a new phenomenon with clinical implications. Bone Marrow Transplant 2011;46:1016-1017.

77. Morrissey CO, Chen SC, Sorrell TC, Milliken S, Bardy PG, Bradstock KF, Szer J, Halliday CL, Gilroy NM, Moore J, Schwarer AP, Guy S, Bajel A, Tramontana AR, Spelman T, Slavin MA; Australasian Leukaemia Lymphoma Group and the Australia and New Zealand Mycology Interest Group. Galactomannan and PCR versus culture and histology for directing use of antifungal treatment for invasive aspergillosis in high-risk haematology patients: a randomised controlled trial. Lancet Infect Dis 2013;13:519-528.

78. Blennow O, Remberger M, Klingspor L, Omazic B, Fransson K, Ljungman P, Mattsson J, Ringden O. Randomized PCRbased therapy and risk factors for invasive fungal infection 
following reduced-intensity conditioning and hematopoietic SCT. Bone Marrow Transplant 2010;45:1710-1718.

79. Rotstein C, Bow EJ, Laverdiere M, Ioannou S, Carr D, Moghaddam N. Randomized placebo-controlled trial of fluconazole prophylaxis for neutropenic cancer patients: benefit based on purpose and intensity of cytotoxic therapy. The Canadian Fluconazole Prophylaxis Study Group. Clin Infect Dis 1999;28:331-340.

80. Wingard JR, Merz WG, Rinaldi MG, Johnson TR, Karp JE, Saral R. Increase in Candida krusei infection among patients with bone marrow transplantation and neutropenia treated prophylactically with fluconazole. N Engl J Med 1991;325:1274-1277.

81. Abbas J, Bodey GP, Hanna HA, Mardani M, Girgawy E, Abi-Said D, Whimbey E, Hachem R, Raad I. Candida krusei fungemia. An escalating serious infection in immunocompromised patients. Arch Intern Med 2000;160:2659-2664.

82. Barberan J, Mensa J, Llamas JC, Ramos IJ, Ruiz JC, Marín JR, Tello PB, Massana MB, Vidal JB, Vinas JM, Huelva FJ, Pons EC, Mediavilla JD, Morfa ML, Barrigón FE, Avellan PF, Lopez SG, García CG, Maraver DH, Guía AL, Jimenez JL, Chacon EM, Rubio MO, Oteyza JP, Ramírez GR, Contreras RR, Barbero AR, Tarrats MR, Felix DR, Godoy PS, Salinas AS, Alonso MA, Torroba Jde L, Ferreiras DV, Lopez LV, García JM, Perea JR, Moreno RC, Cancer RC, Abete JF, Rodriguez JG, Gomez JG, Pedrosa EG, Baranda JM, García FJ, Camps IR, Lleti MS, Cisneros Jde L; Spanish Society of Chemotherapy. Recommendations for the treatment of invasive fungal infection caused by filamentous fungi in the hematological patient. Rev Esp Quimioter 2011;24:263-270.

83. Pagano L, Caira M, Cuenca-Estrella M. The management of febrile neutropenia in the posaconazole era: a new challenge? Haematologica 2012;97:963-965.

84. Marr KA, Laverdiere M, Gugel A, Leisenring W. Antifungal therapy decreases sensitivity of the Aspergillus galactomannan enzyme immunoassay. Clin Infect Dis 2005;40:1762-1769.

85. Cornely OA, Böhme A, Reichert D, Reuter S, Maschmeyer G, Maertens J, Buchheidt D, Paluszewska M, Arenz D, Bethe U, Effelsberg J, Lövenich H, Sieniawski M, Haas A, Einsele H, Eimermacher H, Martino R, Silling G, Hahn M, Wacker S, Ullmann AJ, Karthaus M; Multinational Case Registry of the Infectious Diseases Working Party of the German Society for Hematology and Oncology. Risk factors for breakthrough invasive fungal infection during secondary prophylaxis. J Antimicrob Chemother 2008;61:939-946.

86. Offner F, Cordonnier C, Ljungman P, Prentice HG, Engelhard D, De Bacquer D, Meunier F, De Pauw B. Impact of previous aspergillosis on the outcome of bone marrow transplantation. Clin Infect Dis 1998;26:1098-1103.

87. Fukuda T, Boeckh M, Guthrie KA, Mattson DK, Owens S, Wald A, Sandmaier BM, Corey L, Storb RF, Marr KA.
Invasive aspergillosis before allogeneic hematopoietic stem cell transplantation: 10-year experience at a single transplant center. Biol Blood Marrow Transplant 2004;10:494-503.

88. Avivi I, Oren I, Haddad N, Rowe JM, Dann EJ. Stem cell transplantation post invasive fungal infection is a feasible task. Am J Hematol 2004;75:6-11.

89. Bjerke JW, Meyers JD, Bowden RA. Hepatosplenic candidiasis-a contraindication to marrow transplantation? Blood 1994;84:2811-2814.

90. Sipsas NV, Kontoyiannis DP. Clinical issues regarding relapsing aspergillosis and the efficacy of secondary antifungal prophylaxis in patients with hematological malignancies. Clin Infect Dis 2006;42:1584-1591.

91. Sevilla J, Hernandez-Maraver D, Aguado MJ, Ojeda E, Morado M, Hernandez-Navarro F. Autologous peripheral blood stem cell transplant in patients previously diagnosed with invasive aspergillosis. Ann Hematol 2001;80:456-459.

92. Nosari A, Oreste P, Cairoli R, Montillo M, Carrafiello G, Astolfi A, Muti G, Marbello L, Tedeschi A, Magliano E, Morra E. Invasive aspergillosis in haematological malignancies: clinical findings and management for intensive chemotherapy completion. Am J Hematol 2001;68:231-236.

93. Kruger WH, Russmann B, de Wit M, Kroger N, Renges H, Sobottka I, Zander AR. Haemopoietic cell transplantation of patients with a history of deep or invasive fungal infection during prophylaxis with liposomal amphotericin B. Acta Haematol 2005;113:104-108.

94. Zhang P, Song A, Wang Z, Feng S, Qiu L, Han M. Hematopoietic SCT in patients with a history of invasive fungal infection. Bone Marrow Transplant 2009;43:533-537.

95. Cordonnier C, Rovira M, Maertens J, Olavarria E, Faucher C, Bilger K, Pigneux A, Cornely OA, Ullmann AJ, Bofarull RM, de la Camara R, Weisser M, Liakopoulou E, Abecasis M, Heussel CP, Pineau M, Ljungman P, Einsele H; Voriconazole for Secondary Prophylaxis of Invasive Fungal Infections in Patients With Allogeneic Stem Cell Transplants (VOSIFI) study group; Infectious Diseases Working Party, European Group for Blood and Marrow Transplantation. Voriconazole for secondary prophylaxis of invasive fungal infections in allogeneic stem cell transplant recipients: results of the VOSIFI study. Haematologica 2010;95:1762-1768.

96. Alberti C, Bouakline A, Ribaud P, Lacroix C, Rousselot P, Leblanc T, Derouin F; Aspergillus Study Group. Relationship between environmental fungal contamination and the incidence of invasive aspergillosis in haematology patients. J Hosp Infect 2001;48:198-206.

97. Benet T, Nicolle MC, Thiebaut A, Piens MA, Nicolini FE, Thomas X, Picot S, Michallet M, Vanhems P. Reduction of invasive aspergillosis incidence among immunocompromised patients after control of environmental exposure. Clin Infect Dis 2007;45:682-686. 
98. Center for International Blood and Marrow Transplant Research (CIBMTR); National Marrow Donor Program (NMDP); European Blood and Marrow Transplant Group (EBMT); American Society of Blood and Marrow Transplantation (ASBMT); Canadian Blood and Marrow Transplant Group (CBMTG); Infectious Disease Society of America (IDSA); Society for Healthcare Epidemiology of America (SHEA); Association of Medical Microbiology and Infectious Diseases Canada (AMMI); Centers for Disease Control and Prevention (CDC). Guidelines for preventing infectious complications among hematopoietic cell transplant recipients: a global perspective. Bone Marrow Transplant 2009; 44:453-558.

99. Menegueti MG, Ferreira LR, Silva MF, Silva AS, BellissimoRodrigues F. Assessment of microbiological air quality in hemato-oncology units and its relationship with the occurrence of invasive fungal infections: an integrative review. Rev Soc Bras Med Trop 2013;46:391-396.

100. Sehulster L, Chinn RY; CDC; HICPAC. Guidelines for environmental infection control in health-care facilities. Recommendations of CDC and the Healthcare Infection Control Practices Advisory Committee (HICPAC). MMWR Recomm Rep 2003;52:1-42.

101. Brun CP, Miron D, Silla LM, Pasqualotto AC. Fungal spore concentrations in two haematopoietic stem cell transplantation (HSCT) units containing distinct air control systems. Epidemiol Infect 2013;141:875-879.

102. Abdul Salam ZH, Karlin RB, Ling ML, Yang KS. The impact of portable high-efficiency particulate air filters on the incidence of invasive aspergillosis in a large acute tertiarycare hospital. Am J Infect Control 2010;38:e1-7.

103. Passweg JR, Rowlings PA, Atkinson KA, Barrett AJ, Gale RP, Gratwohl A, Jacobsen N, Klein JP, Ljungman P, Russell JA, Schaefer UW, Sobocinski KA, Vossen JM, Zhang MJ, Horowitz MM. Influence of protective isolation on outcome of allogeneic bone marrow transplantation for leukemia. Bone Marrow Transplant 1998;21:1231-1238.

104. Kruger WH, Zollner B, Kaulfers PM, Zander AR. Effective protection of allogeneic stem cell recipients against aspergillosis by HEPA air filtration during a period of construction--a prospective survey. J Hematother Stem Cell Res 2003;12:301-307.

105. National Disease Surveillance Centre. National Guidelines for the Prevention of Nosocomial Invasive Aspergillosis During Construction/RenovationActivities. Dublin, Ireland, National Disease Surveillance Center, 2002. Available online at https:// www.hpsc.ie/A-Z/MicrobiologyAntimicrobialResistance/ InfectionControlandHAI/Guidelines/File,896,en.pdf.
106. Small TN, Cowan MJ. Immunization of hematopoietic stem cell transplant recipients against vaccine-preventable diseases. Expert Rev Clin Immunol 2011;7:193-203.

107. Kumar D, Chen MH, Welsh B, Siegal D, Cobos I, Messner HA, Lipton J, Humar A. A randomized, double-blind trial of pneumococcal vaccination in adult allogeneic stem cell transplant donors and recipients. Clin Infect Dis 2007;45:1576-1582.

108. Rubin LG, Levin MJ, Ljungman P, Davies EG, Avery R, Tomblyn M, Bousvaros A, Dhanireddy S, Sung L, Keyserling H, Kang I. 2013 IDSA clinical practice guideline for vaccination of the immunocompromised host. Clin Infect Dis 2014;58:e44-100.

109. Eliakim-Raz N, Vinograd I, Zalmanovici Trestioreanu A, Leibovici L, Paul M. Influenza vaccines in immunosuppressed adults with cancer. Cochrane Database Syst Rev 2013;10:CD008983.

110. Hilgendorf I, Freund M, Jilg W, Einsele H, Gea-Banacloche J, Greinix H, Halter J, Lawitschka A, Wolff D, Meisel R. Vaccination of allogeneic haematopoietic stem cell transplant recipients: report from the international consensus conference on clinical practice in chronic GVHD. Vaccine 2011;29:2825-2833.

111. Hamad M. Universal fungal vaccines: could there be light at the end of the tunnel? Hum Vaccin Immunother 2012;8:1758-1763.

112. Dan JM, Levitz SM. Prospects for development of vaccines against fungal diseases. Drug Resist Updat 2006;9:105-110.

113. Cassone A, Casadevall A. Recent progress in vaccines against fungal diseases. Curr Opin Microbiol 2012;15:427-433.

114. Cassone A. Fungal vaccines: real progress from real challenges. Lancet Infect Dis 2008;8:114-124.

115. Rüping MJ, Heinz WJ, Kindo AJ, Rickerts V, Lass-Flörl C, Beisel C, Herbrecht R, Roth Y, Silling G, Ullmann AJ, Borchert K, Egerer G, Maertens J, Maschmeyer G, Simon A, Wattad M, Fischer G, Vehreschild JJ, Cornely OA. Forty-one recent cases of invasive zygomycosis from a global clinical registry. J Antimicrob Chemother 2010;65:296-302.

116. Auberger J, Lass-Florl C, Aigner M, Clausen J, Gastl G, Nachbaur D. Invasive fungal breakthrough infections, fungal colonization and emergence of resistant strains in high-risk patients receiving antifungal prophylaxis with posaconazole: real-life data from a single-centre institutional retrospective observational study. J Antimicrob Chemother 2012;67:2268-2273.

117. Pagano L, Caira M. The role of primary antifungal prophylaxis in patients with haematological malignancies. Clin Microbiol Infect 2014;20(Suppl 6):19-26. 
118. Winston DJ, Bartoni K, Territo MC, Schiller GJ. Efficacy, safety, and breakthrough infections associated with standard long-term posaconazole antifungal prophylaxis in allogeneic stem cell transplantation recipients. Biol Blood Marrow Transplant 2011;17:507-515.

119. Hoenigl M, Raggam RB, Salzer HJ, Valentin T, Valentin A, Zollner-Schwetz I, Strohmeier AT, Seeber K, Wölfler A, Sill H, Krause R. Posaconazole plasma concentrations and invasive mould infections in patients with haematological malignancies. Int J Antimicrob Agents 2012;39:510-513.

120. Ziakas PD, Kourbeti IS, Mylonakis E. Systemic antifungal prophylaxis after hematopoietic stem cell transplantation: a meta-analysis. Clin Ther 2014;36:292-306.e1.
121. Girmenia C, Barosi G, Piciocchi A, Arcese W, Aversa F, Bacigalupo A, Bandini G, Bosi A, Busca A, Castagnola E, Caselli D, Cesaro S, Ciceri F, Locasciulli A, Locatelli F, Mikulska M, Pagano L, Prete A, Raiola AM, Rambaldi A. Primary prophylaxis of invasive fungal diseases in allogeneic stem cell transplantation: revised recommendations from a consensus process by Gruppo Italiano Trapianto Midollo Osseo (GITMO). Biol Blood Marrow Transplant 2014:20;1080-1088. 